\title{
The effect of cutting frequency and nitrogen fertilizer rates on dry matter production, nitrogen uptake and herbage nitrate content
}

\author{
L. Sibma and Th. Alberda \\ Centre for Agrobiological Research (CABO), Wageningen, the Netherlands
}

Accepted: 23 September 1980

Key words: herbage production, nitrogen application rates, nitrate contents

\section{Summary}

Dry matter production, nitrogen uptake and nitrate content in relation to nitrogen application rates and cutting frequencies of herbage were compared.

Higher nitrogen application rates increased the herbage yield more at longer growing periods than at higher cutting frequencies. Nitrogen uptake was positively affected by the application rate and not or slightly by the cutting frequency. Consistent with this, appreciably higher $\mathrm{N}$ concentrations (max. $5.4 \%$ ) were found on an average in the herbage at high fertilizer $\mathrm{N}$ rates and frequent cuttings than at lower rates and less frequent cuttings $(1.6 \%)$.

$\mathrm{NO}_{3}$ content increased during the growing season and more so, as the nitrogen application rate per annum was higher and the growing periods longer.

\section{Introduction}

It has been repeatedly demonstrated that dry herbage production of a grassland sward in a temperate climate can amount to 18 to 20 tonnes per ha if sufficient water and nutritional elements are available (Alberda, 1968; Brougham, 1959; Cooper, 1966). One of the major limits to production in practice is insufficiency of nitrogen; it has been established that for maximum production the nitrate concentration in the herbage should not be allowed to fall appreciably below $100 \mathrm{mmol}$ per $\mathrm{kg}$ of dry matter (de Wit et al., 1963; van Burg, 1965). This corresponds to a fertilizer level of 500 to $600 \mathrm{~kg} \mathrm{~N}$ per ha (Ruessink, 1969). If nitrogen is supplied in small quantities each time that the nitrate concentration in the tissue drops below the $100 \mathrm{mmol} / \mathrm{kg}$ DM limit, there is no danger that the concentration will rise above an acceptable level. In practice, however, the amounts given at any time may need to be higher in order to be sufficient for prolonged growing periods. In such cases the nitrate concentration may temporarily rise to much higher values than is necessary for good 
growth. That this can be dangerous appears from the fact that with the steady increase in the use of nitrogenous fertilizer in Western Europe after the second world war, more and more cases of nitrate poisoning in cattle were reported. This caused a new interest in the nitrate concentration in the herbage, but with the emphasis on animal health. In a recent publication Kemp et al. (1978) presented data from which it can be concluded that with a nitrate concentration not exceeding $200 \mathrm{mmol} / \mathrm{kg}$ DM a nitrite poisoning in milking cows is not likely to occur. It has to be emphasized that this value is only on the safe side for grazing cows. The upper limit of the nitrate concentration of grass fed after processing depends, among others, on the composition of the total ration and on the speed with which these rations are consumed. These limits are not considered here.

However there is not only danger for the grazing animal; a high nitrate concentration in the ration fed to ruminants may also lead to the presence of cancer-inducing nitrosamines in meat and milk. The purpose of the experiments described here was to establish relationships between rates of nitrogen fertilization, dry matter production and nitrate concentration in the herbage of swards cut at different frequencies.

\section{Experiments}

The results of three experiments will be presented and discussed. For the sake of comparison a short description of each is given.

\section{Experiment 1}

Year:

Soil:

Site:

Sward:

Cutting frequencies:

Nitrogen application:

\section{Experiment 2}

Year:

Soil:

Site:

Sward:

Cutting frequencies:

Nitrogen application:
1971

Clay with a rather high organic matter content

The polder 'Oostelijk Flevoland'

An eight-year-old pasture containing ca. $90 \%$ perennial ryegrass with a low percentage of couch grass and white clover

6,4 and 3 cuts per annum, growing periods of 35,52 and 70 days, respectively

See Table 1

\section{6}

Rather humid sandy soil with a high organic matter content

Wageningen

Perennial ryegrass ley, sown September 1975

Before seeding the mixture in September 1975, a very old grass sward was disked intensively through the upper soil layers so that a high fertility level could be expected

$28,9,6$ and 4 cuts per annum, growing periods of 7,21 , 35 and 49 days, respectively

See Table 1 
Table 1. Cutting frequencies and $\mathbf{N}$ dressings in the experiments.

\begin{tabular}{|c|c|c|c|c|c|c|c|c|c|c|}
\hline \multirow{2}{*}{$\begin{array}{l}\text { Experiment number } \rightarrow \\
\text { Registration number } \rightarrow\end{array}$} & \multicolumn{3}{|c|}{1} & \multicolumn{4}{|c|}{2} & \multicolumn{3}{|c|}{3} \\
\hline & \multicolumn{3}{|c|}{ IBS 1470-1971 } & \multicolumn{4}{|c|}{ САBO 47-1976 } & \multicolumn{3}{|c|}{ CABO 162-1977 } \\
\hline Growing period cut ${ }^{-1} \rightarrow$ & 35 & 52 & 70 & 7 & 21 & 35 & 49 & 14 & 28 & 42 \\
\hline Number of cuts year ${ }^{-1} \rightarrow$ & 6 & 4 & 3 & 28 & 9 & 6 & 4 & 12 & 6 & 4 \\
\hline \multicolumn{11}{|l|}{$\mathrm{N} \mathrm{ha}^{-1}$ annum ${ }^{-1}$} \\
\hline 0 & + & + & + & & + & & + & & & \\
\hline 120 & + & + & + & & & & & & & \\
\hline 200 & & & & & & + & + & + & + & + \\
\hline 240 & + & + & + & & & & & & & \\
\hline 360 & + & + & + & & & & & & & \\
\hline 400 & & & & & + & + & + & + & + & + \\
\hline 480 & + & + & + & & & & & & & \\
\hline 600 & + & + & + & + & + & + & + & + & + & + \\
\hline 800 & & & & + & + & + & + & + & + & + \\
\hline 1000 & & & & + & + & + & & & & \\
\hline
\end{tabular}

$+=$ present

\section{Experiment 3}

Year:

Soil:

Site:

Sward:

Cutting frequencies:

Nitrogen application:

\section{7}

Clay with a low organic matter content

The polder 'Oostelijk Flevoland'

Perennial ryegrass ley, sown in the autumn of 1975

12,6 and 4 cuts per annum, growing periods of 14, 28 and 42 days, respectively

All three experiments were carried out in triplicate. At each harvest strips $10 \mathrm{~m} \times$ $0.8 \mathrm{~m}$ were mown to provide samples for dry weight determinations and chemical analyses, a small motor mower being used for all defoliations except the weekly defoliations in Experiment 2. To allow adequate recovery of the short herbage in this treatment the plots were cut with a lawn mower, and the cuttings were blown into a container attached to the mower.

For chemical analyses the three replicates were bulked after drying and milling. Total nitrogen, nitrate nitrogen and total water-soluble carbohydrates were determined.

\section{Results}

Dry herbage production and nitrogen uptake in relation to nitrogen fertilizer application

The effects of nitrogen dressings on the total amounts of dry matter produced and of nitrogen taken up by the swards over the growing season are presented in Fig. 1ac. In this presentation the method of Frankena \& de Wit (1958) was followed. Qua- 


\section{SIBMA AND TH. ALBERDA}
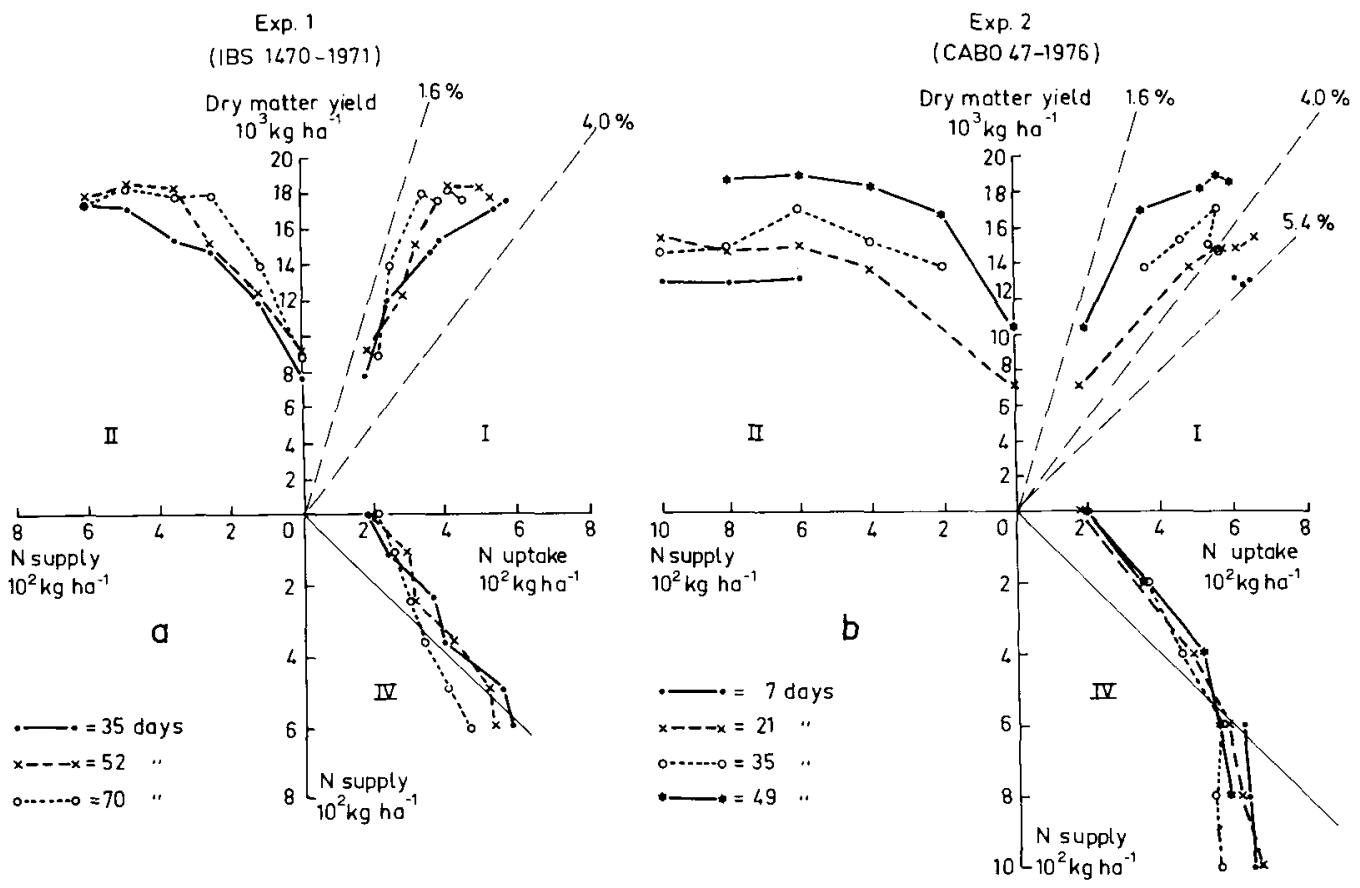

Exp. 3

(CABO 162-1977)

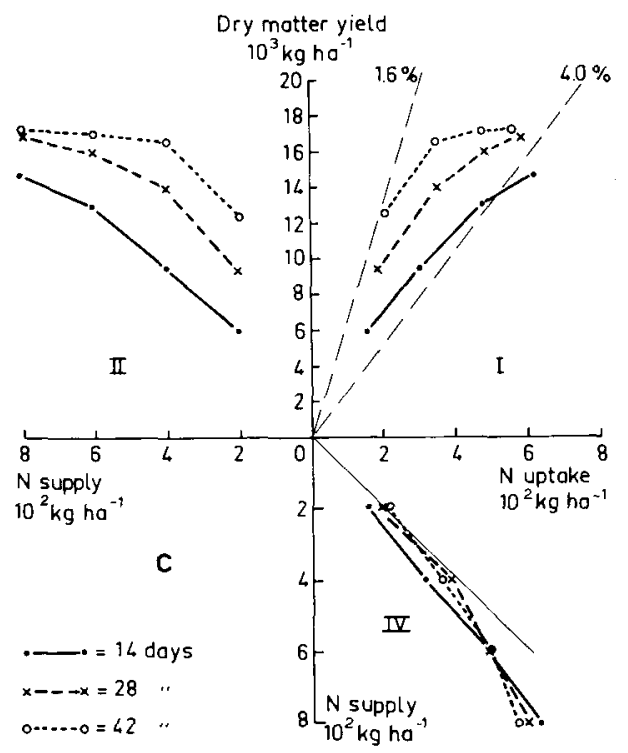

Fig. 1. Effect of frequencies and $\mathbf{N}$ dosages on the relation between $\mathrm{N}$ uptake and dry matter yield (quadrant 1 ), $\mathrm{N}$ supply and dry matter yield (quadrant II) and $\mathrm{N}$ supply and $\mathrm{N}$ uptake (quadrant IV). The thin dashed lines indicate the total $\mathrm{N}$ content in the dry matter. 
drant I shows the relationship between total dry herbage production and the total amount of nitrogen taken up by the sward; quadrant II the relationship between total dry herbage production and nitrogen application and quadrant IV the relationship between nitrogen application and nitrogen uptake.

It can be seen that the maximum annual herbage yield centers around $18000 \mathrm{~kg}$ per ha and per annum, a yield also found in many earlier experiments in which the supply of water and plant nutrients was supposed to be optimal. Because the water supply was not always sufficient in these experiments, deviations from the optimum situation were possible. This was certainly so in the second experiment, which was carried out in 1976, a year with very dry spells coupled with high radiation. The 35 day cutting frequency was particularly affected because one cut coincided with such a dry spell.

It can be concluded from quadrant II that the dry herbage per season increased with the length of the growing period. This is usually more evident at lower nitrogen fertilizer levels. For a growing period of 49 days or more the maximum dry herbage production is obtained with $400 \mathrm{~kg} \mathrm{~N}$ per ha; for shorter growing periods more nitrogen seems necessary. Experiments 2 and 3 indicate that the maximum level of productivity could not be reached when the growing periods were very short. Nevertheless it can be seen from Experiment 2 that a total dry herbage production of 13 tonnes per ha per annum could be obtained even when the swards were cut every 7 days.

The relationship between nitrogen supply and nitrogen uptake is presented in quadrant IV of Fig. 1. The three experiments agree in so far this relationship is a linear one up to applications of 400 to $500 \mathrm{~kg} \mathrm{~N}$ per ha, but differ in the $\mathrm{N}$ uptake at zero $\mathrm{N}$ application and in the relationship between supply and uptake at levels higher than $600 \mathrm{~kg} \mathrm{~N}$ per ha. In Experiments 1 and 2 the uptake at zero $\mathrm{N}$ application amounted to approximately $200 \mathrm{~kg} \mathrm{~N}$ per ha per annum, but an extrapolation of the lines to the uptake axis in Experiment 3 indicates a value of at most $50 \mathrm{~kg} \mathrm{~N}$. At a fertilizer level of $600 \mathrm{~kg} \mathrm{~N}$ per ha in Experiment 2 a plateau was reached, but in Experiment 3 the uptake increased distinctly up to $800 \mathrm{~kg} \mathrm{~N}$ per annum, the highest amount applied in this experiment.

The lines in quadrant I presenting the relationship between nitrogen uptake and dry matter yield can be assumed to pass through the origin. The slope of the lines indicates the concentration of nitrogen in the herbage in relation to the amount of $\mathrm{N}$ supplied and to the length of the growing periods. The concentration increases with increasing amounts of fertilizer, especially at higher levels, and with decreasing length of the growing period, although these differences tend to diminish at higher fertilizer levels.

\section{The nitrate concentration of the dry herbage}

At each harvest the dry herbage was also analysed for nitrate. Data from the first and last harvests are presented in Fig. 2: values for intermediate harvests lay between the two extremes in all cases and are not presented.

The results show that the nitrate concentration tends to rise as the level of fertilization increases and also as the length of the growing period increases, especially at 


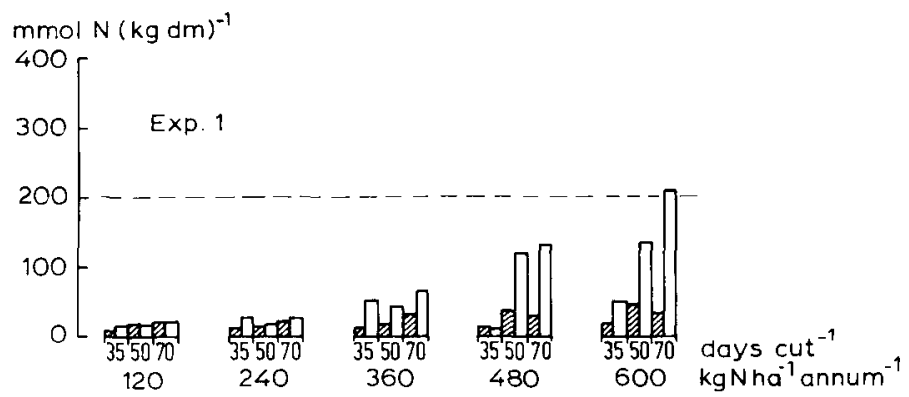

$\mathrm{mmol} \mathrm{N}(\mathrm{kg} \mathrm{dm})^{-1}$

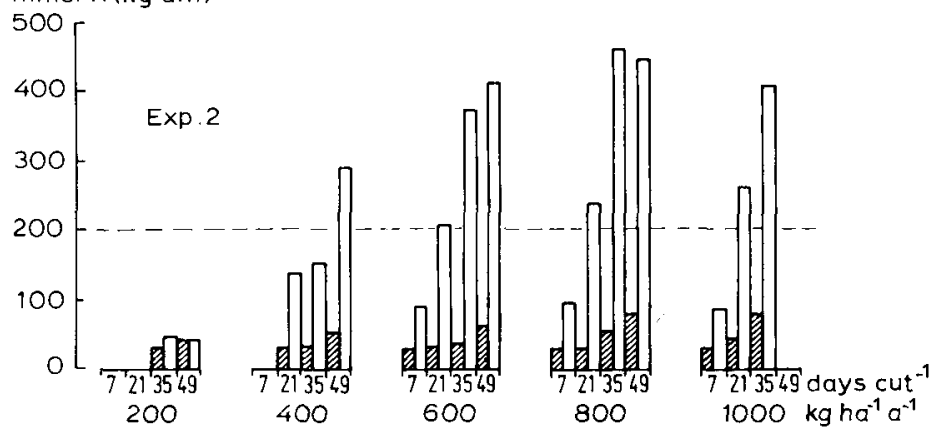

$\operatorname{mmol~} N(\mathrm{~kg} \mathrm{dm})^{-1}$

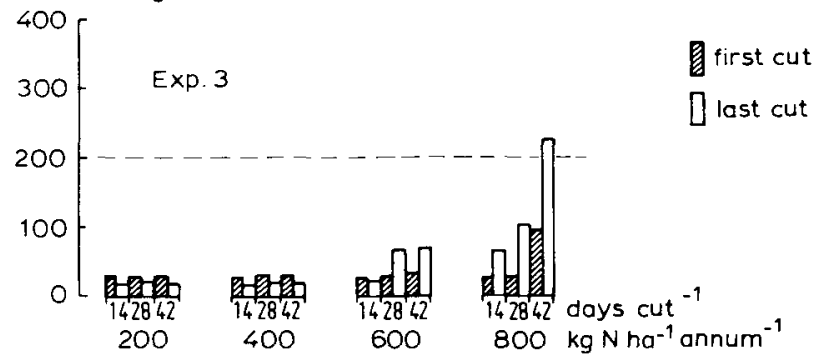

Fig. 2. Influence of nitrogen applications and number of days per cut on nitrate contents in the first and last cuts per growing season.

the higher fertilizer levels. However, it increases most with the advancement of the season, again especially at higher fertilizer levels. The nitrate level of $200 \mathrm{mmol}$ per $\mathrm{kg}$ dry matter is presented in Fig. 2 as a dashed line. Values above this level may cause nitrite poisoning of cattle. These levels occur in autumn grass only and in Experiments 1 and 3 are confined to the longest growing period and the highest fertilizer application. In Experiment 2 the nitrate levels in autumn were much higher and the criticial $200 \mathrm{mmol}$ level was reached at lower levels of fertilizer and over a range of cutting frequencies. 


\section{Discussion}

The effect of a wide range of levels of applied nitrogen was studied as early as 1949 by Mulder, who supplied as much as $2520 \mathrm{~kg} \mathrm{~N}$ per ha per annum. In recent studies such levels have been combined with a similarly wide range of cutting frequencies (Jung et al., 1974; le Clerc, 1976; Wilman et al., 1976; Bartholomew \& Chestnutt, 1977; Chestnutt et al., 1977). Growing periods varied from 112 days (Bartholomew \& Chestnutt, 1977) to a little over a week (le Clerc, 1976 with 21 cuts per season with varying intervals). As far as the effects of both duration of the growing period and the amount of nitrogen applied on dry matter production are concerned, there is general agreement between the data in literature and our experiments. The amount of dry herbage increases with increasing length of the growing period up to the longest period of 112 days. This is apparently because the periods without a complete grass cover increase with the cutting frequency so that a greater part of the incoming radiation is not absorbed by photosynthesizing tissue. There is usually a maximum amount of fertilizer above which the amount of dry herbage remains more or less constant or even decreases when the nitrogen is either applied in large doses per application (Chestnutt et al., 1977) or at rates per annum exceeding $1000 \mathrm{~kg} \mathrm{~N}$ per ha (Mulder, 1949; Bartholomew \& Chestnutt, 1977; le Clerc, 1976). The yield differences for different growing periods usually decrease with higher doses of fertilizer, so that the decreased yield due to a short growing period can at least partly be compensated for by high doses of nitrogen as long as the cutting frequency is not too high (Experiment 1 and 3, Fig. 1).

Quadrant II shows that the variation is too large to indicate a minimum fertilizer level for maximum herbage production for each growing period. This is understandable because quadrant IV indicates considerable differences in nitrogen uptake at zero fertilizer level. Weather conditions will also have an influence, especially since irrigation was not always applied. Taking into account results from earlier experiments (Alberda, 1972), the general conclusion is that a maximum yield between 18 and 20 tonnes of dry herbage per season can be obtained at fertilizer levels around $500-600 \mathrm{~kg} \mathrm{~N}$ per ha per annum.

The relationship between the amount of fertilizer applied and that taken up by the herbage (quadrant IV) seems to be linear at low fertilizer levels. It is sometimes suggested that this is a general rule (van Keulen, 1977), but where the range of application is large enough, as in Experiment 2 with applications up to $1000 \mathrm{~kg} \mathrm{~N}$ per ha per annum, the relationship is seen to be more like the concentration-uptake function observed in many experiments with nutrient solutions (see e.g. Alberda, 1973).

In quadrant IV the thin solid line indicates a situation in which the nitrogen removal with the crop is equal to the amount of nitrogen applied as fertilizer. In Experiments 1 and 2 at low application levels more nitrogen is removed than is given; at a value between 400 and $500 \mathrm{~kg} \mathrm{~N}$ applied an equal amount is removed, and above that value a part of the nitrogen applied is not recovered. In Experiment 3, however, the equilibrium between dosage and removal lies around $200 \mathrm{~kg} \mathrm{~N}$. This difference is due to the fact that in this experiment much less nitrogen is taken up at zero application. These differences are possibly related to the fact that 
Experiments 1 and 2 were carried out on older grassland ( 8 years or more), whereas Experiment 3 was situated on a soil in the polder that had only carried arable crops for a few years after the reed had been burned down and before it was sown to grass in the year preceding the experiment. The soil was known to be poor in available nitrogen for a few years after reclamation. If one looks at the situation in which just as much nitrogen is removed with the herbage as has been applied as fertilizer, one could argue that apparently not much nitrogen is lost.

However, the amount of nitrogen taken up by the herbage at zero application is often quite substantial ( $200 \mathrm{~kg} \mathrm{~N}$ in Experiments 1 and 2) and is supposed to be set free from the organic soil nitrogen reserve which has often been reported to amount to tonnes of $\mathrm{N}$. It is possible that a similar amount of soil nitrogen is set free at higher levels of fertilizer input but that a proportion of the total $\mathrm{N}$ in the system is being washed down into the soil and may being released into surface waters. Further investigations in which account is being taken of the nitrogen content of the soil and of residual fertilizer effects are in progress and should help to clarify this important point.

The concentration of nitrogen in the herbage as an average over the growing season varies between $1.6 \%$ at low fertilizer and $4 \%$ at the higher levels. These limits are indicated in Fig. 1a-c and are in good agreement with earlier observations (Alberda, 1972). When, however, fertilizer inputs of $800 \mathrm{~kg} \mathrm{~N}$ or more are combined with growth periods of 21 days or less the nitrogen in the herbage may exceed the $4 \%$ level. The highest value of $5.4 \%$ was found in grass cut weekly and fertilized with $1000 \mathrm{~kg} \mathrm{~N}$ per ha per annum. These results support the findings of Bartholomew \& Chestnutt (1977), who found levels above $4 \% \mathrm{~N}$ with applications of 900 or $1500 \mathrm{~kg} \mathrm{~N}$ combined with a 22 days growing period. The nitrogen concentration also varies with the season in the sense that the lowest values were found during flowering and seed setting with a steady increase towards September and October. However, in the harvests in late October and November the percentages showed a tendency to drop.

Most of the nitrogen in the herbage is in organic form. When enough nitrogen is applied to obtain maximum herbage production the crude protein content is usually higher than necessary in an animal feed, even for milking cows. This means that part of the protein could, in theory, be extracted before feeding the grass to ruminants. According to Wieringa (1978) this extractable quantity can easily amount to $500 \mathrm{~kg}$ protein per ha per annum. Whether or not such a technique is economically feasible is not within the scope of this paper.

Another important consideration when ruminants are fed with grass grown at a high nitrogen level is the nitrate content in the herbage and the danger of nitrite poisoning. When the value of Kemp \& Geurink (1978) is considered as a safe limit for grazing cows ( $200 \mathrm{mmol} \mathrm{kg} \mathrm{kg}^{-1}=0.28 \% \mathrm{~N}$ in the dry herbage) it can in general be concluded that no serious risk of poisoning occurs when the amount of fertilizer does not exceed $600 \mathrm{~kg} \mathrm{~N}$ per ha per annum and the cutting interval is shorter than 4 weeks. That one has to be very careful, however, appears from the very high nitrate values in Experiment 2 (Fig. 2). These values, found in the autumn of the very dry year 1976 are probably due to the fact that the nitrogen was supplied in equal por- 
tions after each cutting and that during a drought period growth was hampered to such an extent that not all the nitrogen applied was taken up. With the following rain so much accumulated nitrogen was available that these extreme values could occur. Although it is clear that maximum productivity can usually be obtained without toxic nitrate concentrations extreme climatic conditions can cause rapid changes over a great range and it seems necessary to collect more information about the factors that influence these fluctuations.

\section{References}

Alberda, Th., 1968. Maximale grasproduktie. Stikstof No 60: 538-545.

Alberda, Th., 1972. Nitrogen fertilization of grassland and the quality of surface water. Stikstof No 15: 45-51.

Alberda, Th., 1973. Potential protein production of temperate grasses. In: J. G. W. Jones (Ed), The biological efficiency of protein production. Cambridge University, pp. 119-130.

Bartholomew, P. W. \& D. M. B. Chestnutt, 1977. The effect of a wide range of fertilizer nitrogen application rates and defoliation intervals on the dry matter production, seasonal response to nitrogen persistence and aspects of chemical composition of perennial ryegrass. J. agric. Sci., Camb. 88: $711-724$.

Brougham, R. W., 1959. The effects of season and weather on the growth rate of a ryegrass and clover pasture. N.Z. Jl agric. Res. 2(2) 285-296.

Burg, P. F. J. van, 1965. De stikstofbemesting van grasland. 7. Het nitraatgehalte als indicator voor de stikst ofvoeding. Stikstof No 47: 461-469.

Chestnutt, D. M. B., J. C. Murdoch, F. J. Harrington \& R. C. Binnie, 1977. The effect of cutting frequency and applied nitrogen on production and digestibility of perennial ryegrass. J. Br. Grassld Soc. 32: $177-183$.

Clerc, M. H. le, 1976. Effects of nitrogen and restperiods on the seasonal production of the pure grass sward. I. Dry matter production. Ir. J. agric. Res. 15: 247-255.

Cooper, J. P., 1966. The significance of genetic variation in light interception and conversion for forage plant breeding. Proc. 10th int. Grassld Congr. (Helsinki) 715-720.

Frankena, H. J. \& C. T. de Wit, 1958. Stikstofbemesting, stikstofopname en grasgroei. Landbouwk. Tijdschr. 70: 465-472.

Jung, G. A., J. A. Balasko, F. L. Alt \& L. P. Stevens, 1974. Persistence and yield of ten grasses in response to clipping frequency and applied nitrogen in the Allegheni Highlands. Agron. J. 66: 517-521.

Kemp, A., J. H. Geurink, A. Malestein \& A. Th. van 't Klooster, 1978. Grassland production and nitrate poisoning in cattle. Proc. 7th gen. Meet. Eur. Grassld Fedn.: 9.1-9.15.

Keulen, H. van, 1977. Nitrogen requirements of rice with special reference to Java. Contr. Centr. Res. Inst. Bogor 30: 1-77.

Mulder, E. G., 1949. Onderzoekingen over de stikstofvoeding van landbouwgewassen. I. Proeven met kalkammonsalpeter op grasland. Versl. landbouwk. Onderz. 55.7: 1-95.

Ruessink, G., 1969. Drogestofproductie van en lichtabsorptie door grassen. Internal Research Report, IBS, Wageningen.

Wieringa, G. W., 1978. Influence of $N$ fertilizer and cutting frequency on the extraction of protein from grass. Proc. 7th gen. Meet. Eur. Grassld Fedn.: 9.1-9.15.

Wilman, D., D. Droushiotis, A. Koocheki, A. B. Lwoga \& J. S. Shim, 1976. The effect of interval between harvests and nitrogen application on the proportion and yield of crop fractions in four ryegrass varieties in the first harvest year. J. agric. Sci., Camb. 86: 189-203.

Wit, C. T. de, W. Dijkshoorn \& J. C. Noggle, 1963. Ionic balance and growth of plants. Versl. landbouwk. Onderz. 69.15: 1-68. 